\title{
Research on the Integration and Growth Mechanism of Chinese Traditional Culture and Enterprise Party Construction
}

\author{
Qin Wang \\ Wuhan University of Technology \\ Wuhan, China 430070
}

\author{
Jiangjing Xia \\ Wuhan University of Technology \\ Wuhan, China 430070
}

\begin{abstract}
Chinese traditional culture has a long history, extensive and profound, containing rich philosophical thought, moral ideas and a strong spiritual power. Chinese excellent traditional culture is not only an important content of socialist cultural construction and a source of thought, but also nourished the great Chinese Communist Party. From the perspective of traditional Chinese cultural resources, this paper discusses the embodiment and application of traditional culture in enterprise party building, analyze and explore the problems of combining traditional culture with enterprise party building. To absorb the reasonable core of traditional Chinese culture and promote the development of enterprise party construction is an important aspect of party building in the new era.
\end{abstract}

Keywords-Chinese traditional culture; enterprise party building; integration

\section{INTRODUCTION}

During the period of socialist modernization, the development of society cannot be separated from the contribution of enterprises. The development of party building in enterprises is also crucial, related to the leadership of the party, social harmony and stability, therefore, strengthening and improving Party building is of great significance. Chinese excellent traditional culture is the spiritual lifeblood of the Chinese nation, and also the source of the advanced culture of the Chinese Communist party. General Secretary Xi Jinping pointed out that the traditional culture of those who can regulate the behavior of people and coordinate social relations in the new era conditions should be given its new meaning. How to draw spiritual strength from excellent traditional culture is a major theoretical and practical subject of enterprise party construction. [1]

\section{THE RELATIONSHIP BETWEEN TRADITIONAL CULTURE AND ENTERPRISE PARTY BUILDING}

In the long course of historical development, after longterm exchanges and integration the Chinese people formed its profound excellent traditional culture. The value system, ethical norms and behavioral methods of traditional culture are deeply melted in people's ideological and behavioral norms, affecting people's psychology and personality, penetrating in social life and ideology of all aspects, restricting the development of social history. In terms of personal value, emphasizing the independent selftranscendence; social value focus on innovation and boldness; national value pursuit of strive for progress with determination and national rejuvenation. These excellent traditional culture not only with the party's own construction in line, but also for the majority of party members to improve their moral quality to provide a reference system. Dig into the excellent resources in the traditional culture, strengthen the ideological and moral construction of Party members in the enterprise, and consolidate the party's ruling foundation. From "A just cause enjoys abundant support, an unjust cause finds scant support" to "water can carry a boat, can also capsize", from "serve the people" to "people-oriented" purpose, reflects the party's principle that the party's roots in the people, blood in the people, power in the people. [2] In addition, the party members have to read some excellent classic books, to accept the influence of excellent traditional culture is conducive to being frank with each other in the relationship between people; in the relationship between man and nature, be kind to all things and live in harmony; between countries and nations achieve mutual respect, and be able to make compatible and inclusive cultures for different ethnic groups. Through corresponding education of traditional culture, inherited and penetration, effective subtly to the employees' values and behavior manner corresponding change, to improve the level of the employee's values, to provide strong spiritual power for the enterprise party construction development. Traditional culture and enterprise party building are closely related to each other. Enterprise party construction has its own characteristics, and it is an inseparable part of the party building of the Communist Party of china. The development of Party Construction in enterprises is inseparable from the traditional culture, and the traditional culture can fully nourish the party construction of enterprises, and has a positive role in the development of enterprises. 


\section{THE REFERENCE OF TRADITIONAL CULTURE TO PARTY BUILDING IN ENTERPRISES}

\section{A. Adhering to the People-oriented Principle in Enterprise Party Construction}

The traditional culture of the "people-oriented", "the people are more important than the ruler", "The people are masters of the king for the guests" ideas have shown that the government should strive to make people rich. People are the fundamental of the country. Only by paying close attention to the people's livelihood and thinking what the people think and what the people are anxious about, can the society continue to progress and the state can be at peace. The development of modern economy and society has created enormous material wealth. In this process, we should not only pay attention to the growth of wealth, but also attach importance to the value and function of human beings. Confucius advocated "The benevolent loves others." to promote the simple "people-oriented" philosophy, demonstrate that we should pay attention to the interests of the broad masses of the people, and wholeheartedly serve the people. Enterprise party building work is mainly a man's work. The role of party organizations in enterprises is not only reflected in the development of enterprises, but also to reflect the development of employees, enterprises and employees to achieve mutual promotion and coordinated development. Adhere to the people-oriented, in the enterprise party building to focus on the following aspects: First of all, we need to encourage party members to play an exemplary role, and maintain the status of party members, through the establishment of party members within the service center to protect the basic rights of party members. Second, we should actively build a mechanism for serving the masses of the party members, listen to the voice of the masses and pay close attention to the demands of the masses. We should start with the most immediate and practical interests and do practical things for the broad masses of the people. Finally, we should strengthen the evaluation mechanism innovation of Party building activities and enhance the effectiveness of Party Construction activities. Close to the actual situation of enterprises, strengthen party construction process management, at the same time take the form that masses of people love to see, insist in the enterprise from the masses come to the masses of work method, and focus the masses' opinions. In the building and development of the party building, we must profoundly understand the traditional culture of people's thinking, create a more comfortable environment for employees. Consciously establish "peopleoriented" thought, attaches great importance to the people's enthusiasm and creativity, enable enterprises to make more contributions to the society, the employees are fully comprehensive development, finally realizes the enterprise value and the value of a man.

\section{B. Paying Attention to Criticism and Self-criticism in Enterprise Party Construction}

China since ancient times is the ancient civilization, etiquette of the state. The ancients talk about the three decrees that to set one's virtue, to set one's meritorious, To expound one's ideas in writing, but also put virtue in the first place. Confucianism culture focuses on moral cultivation, emphasizing "To cultivate the moral self, regulate the family, maintain the state rightly and run the state". Confucius that the specific way to "self-cultivation" is "introspection", "When we see men of worth, we should think of equaling them; when we see men of a contrary character, we should turn inwards and examine ourselves." Through the external moral education law and internal self-education law both inside and outside the combination of two-pronged approach to improve people's moral standards. Enterprise Party building pays attention to criticism and self-criticism of the ideological method, which is the traditional culture of selfcultivation spirit of the inheritance. Mao Zedong pointed out "inner-party criticism is the organization of the strong party and the weapon of the Party's fighting." In the process of enterprise party building, we must adhere to the study, downto-earth, conscientious, self-cultivation of the world outlook, and truly down the body, down the force. People who are born, all knowledge, talent, experience needs to be hard to learn and work practice to get in the enterprise to form a kind of learning, love learning atmosphere. Therefore, enterprises must stand in the strategic height, focus on sustainable development, give full play to the cadres and workers, the enthusiasm and creativity, establish a sound incentive mechanism, within the enterprise to create a strong learning atmosphere, and strive to create learning enterprises and leadership. Only in this way can we master the whole situation in the face of new situations, and new problems.

\section{Insisting on the Combination of Material Civilization Construction and Spiritual Civilization Construction in the Party Building of the Enterprise}

The enterprise strategy pay more attention to economic benefits, despises the development of party building work, Therefore, in the education system of enterprise employees, education of excellent traditional culture must be strengthened. Traditional culture emphasizes the establishment of the correct view of justice and benefit, which is of great significance to the party building of enterprise, and will also enhance the effectiveness of party building work. The view of justice and benefit emphasizes the unity of personal interests and collective interests, and opposes the interests of individuals to harm society. The pursuit of morality is, to some extent, the greatest pursuit of benefit. When the public interest conflicts with the selfish interests, Confucianism advocates "lay down one's life for a just cause" and advocate the spirit of dedication. "Gentleman act according morality, villain act according benefit". To be a virtuous man rather than to be cynical is the basic requirement of Confucianism life. From the requirements of become a useful person and pay attention to morality, Confucianism fully highlights the importance of righteousness. Confucianism does not completely deny pursuit of the benefits, as long as it is not against morality, it can be obtained in a reasonable way, affirming the legitimate material interests of ordinary people. This view of justice and benefit is consistent with the idea that material civilization and spiritual civilization should be held together. Justice is to maintain the social and public interests of the spiritual civilization, including moral quality, ethical norms, 
ideological consciousness, etc. benefit is to protect the basic needs of ordinary people's material interests. Max Weber said: "In any period of history, whenever possible, there will be a cruel profit taking without any ethics."[3] While China's socialist modernization has achieved remarkable achievements, it has been relatively backward in the construction of socialist spiritual civilization, and there are some problems in party conduct and folkway. The concept of justice in traditional culture is of great significance for the party building in the enterprise. Deng Xiaoping said: "Without strengthening the construction of spiritual civilization, the construction of material civilization should be damaged and detour." While developing the economy, enterprises should constantly promote the coordinated development of socialist material civilization, political civilization and spiritual civilization. Excavating the excellent spiritual resources in the traditional culture, using the discipline restraint, the moral standard, the faith firmness in the promotion enterprise development, simultaneously must promote the improvement of enterprise staff's ideological level and promote the development of party building.

\section{The Enterprise Party Construction Integrates the Thought of Faithfulness and Fidelity}

The harmonious culture of enterprise construction is based on the construction of socialist core value system, and the core value system of any time can't be separated from the inheritance of excellent traditional culture. In the process of strengthening party building and construction, traditional culture can provide what kind of reference and inspiration? Confucianism is the core of the traditional Chinese thought, and the essence of Confucian thought is "faithfulness and fidelity; righteousness and the concept of faithfulness and fidelity has a long history in the "family-country integration" society. Loyalty is a virtue of man's devotion to heaven and earth, truth, faith, state and others to fulfill his duties. It is very important to introduce faithfulness and fidelity thoughts into the enterprise staff education. First, educating employees are loyal to the enterprise, loyal to the post, and love their own work. Second, educating employees actively build a harmonious family, honor their parents, respect their elders, and have a good family environment to be fully engaged in their work. Third, let employees learn the excellent connotation of filial piety culture, combine filial piety culture with Party spirit cultivation, guide the majority of employees to filial piety to their parents, care for their families, appreciate enterprises and repay the society.[4]Through the training of civilized etiquette, filial piety culture and other expert knowledge lectures, the enterprise deepens employees' awareness of filial piety culture, and integrates the philanthropic spirit of filial piety culture into the real life. We should promote respect, honesty, caring for others. In the enterprise, pay attention to the exemplary role of typical examples. We need to promote the deeds and virtues of a typical example, integrated into the enterprise party building, to become a powerful weapon to guide employees to learn ideological and political education, ensure that the ideological realm of employees can be sublimated in the process of continuous learning. We should use the essence of traditional culture innovation to carry out party building work, to provide a powerful spirit for the harmonious and scientific development of enterprise party building.

\section{CONCLUSION}

General Secretary Xi Jinping pointed out: "The history and culture, especially the values and moral norms inherited by the ancestors, treat with distinction, inherit with abandon and try to educate people with all the spiritual wealth created by the Chinese nation" [5] In order to achieve all-round development of employees and sustainable development of enterprise party construction, enterprise party building should be dominated by advanced ideology and culture. In carrying out the party building, we should actively practice the Confucian doctrine of "benevolence and wisdom, honesty and diligence". In the enterprise to carry out traditional cultural knowledge lectures, so that employees feel the profound Confucian culture, including traditional Confucianism, Chinese virtue, professional ethics and so on. And be able to cultivate employees' moral sentiments. The majority of employees should establish self-cultivation, comity tolerance and good character. Combining excellent traditional history and culture with work, we can obtain better entry points and avoid the inane and anemic construction of ideological construction. At the same time, the combination of the essence of Chinese traditional culture and modern management means is of great significance to the construction of international enterprises with Chinese characteristics. In the process of building the party building, learn from the traditional Chinese culture the spirit of seeking truth and pay attention to the construction of learning style to form a strong learning atmosphere. Learn from the traditional Chinese culture "unity of knowledge and practice" philosophy, the formation of theory with practice, seeking truth from facts ideological line. Learn from the traditional Chinese culture, "people oriented" ideas, the formation of contact with the masses of the style and "from the masses to come to the masses" of the mass line. Learn from the traditional Chinese culture "sincerity" "Slim" focus on ethics and morals, formed a critical and self-criticism of the fine style. Absorb excellent ideas from traditional culture. Such as self-improvement, the doctrine of the mean thought, absorb all good ideas and attaches great importance to the moral character. On the one hand, we can use excellent traditional culture to strengthen the staff's ideological and moral level. On the other hand, we can use the essence of traditional culture innovation to carry out party building work, to provide a powerful spirit for the harmonious and scientific development of enterprise party building.

\section{REFERENCES}

[1] Kong Hongming, "On the Importance of Chinese Traditional Culture in the Management of Party Building in Enterprises," [J].Xiang Chao Monthly, pp. 35, January 2013

[2] Wang peng, "Into the excellent traditional culture, innovation grassroots party building work," [J].World nonferrous metals, pp. 7879, No. s1 2015. 
[3] Xu Xuchu, "Century Archives: 100 Articles Affecting the History of the World in the 20th Century," [M].Chinese Literature and History Publishing House, pp. 63, 1996.

[4] Wang hui, "Using the Essence of Traditional Culture to Innovate the Party's Construction,” [J].Sinopec, pp. 74-75, October 2011.

[5] Wang Xuan, "The Value Implication of the Combination of Excellent Traditional Culture and Party Construction," [J].People 's Forum, pp. 140-141, No. 352016 